\title{
PENERAPAN SI APIK PADA PEMBUKUAN UMKM SCALE UP JABODETABEK
}

\author{
Tati Rosyati, Fina Fitriyana, Yolanda Gusvia, dan Anum Nuryani \\ Program Studi Manajemen \\ Universitas Pamulang \\ dosen02420@unpam.ac.id
}

\begin{abstract}
This "Pengabdian Kepada Masyarakat (PKM)" is in collaboration with the South Tangerang Institute for Community Empowerment (RPM). The purpose of this PKM is to introduce SAK-EMKM and apply SAK-EMKM to the financial statements of SME actors in an easy way. There are 100 SMEs involved in this PKM with teaching time being carried out simultaneously and together at Pamulang University and divided into groups with a minimum number of 1 (one) 1 (one) UKM service on 24-28 February 2020 Methods used in this PKM is Counseling / lectures, Tutorials, Discussions, Assistance and Assessment. PKM results from groups consisting of 4 (four) devotees and 4 (four) SME participants, only 2 SME participants who were right and disciplined in carrying out books using SI APIK, for a period of 3 months. It is hoped that this PKM will be beneficial for various parties including SMEs themselves, Bank Indonesia, the Indonesian Institute of Accountants, the Government and for academics.
\end{abstract}

Keywords: SAK-EMKM, SI APIK, UMKM, RPM Institute

\begin{abstract}
Abstrak
Pengabdian kepada masyarakat (PKM) ini bekerjasama dengan Rumah Pemberdayaan Masyarakat (RPM) Institute Tangerang Selatan. Tujuan dari PKM ini adalah untuk memperkenalkan SAK-EMKM dan mengaplikasikan SAK-EMKM pada laporan keuangan pelaku UKM dengan cara mudah. Pelaku UKM yang terlibat serta dalam PKM ini berjumlah 100 orang dengan waktu pengajaran dilakukan secara serempak dan bersama-sama di Universitas Pamulang dan dibagi secara berkelompok dengan jumlah minimal 1(satu) pengabdi 1 (satu) UKM pada tanggal 24-28 Februari 2020 Metode yang digunakan dalam PKM ini adalah Penyuluhan/ ceramah, Tutorial, Diskusi, Pendampingan dan Assesment. Hasil PKM dari kelompok yg terdiri 4(empat) pengabdi dan 4(empat) peserta UKM, hanya 2 peserta UKM yang tepat dan disiplin dalam melakukan pembukuan menggunakan SI APIK, selama jangka waktu 3 bulan. Diharapkan PKM ini bermanfaat untuk berbagai pihak diantaranya pelaku UKM itu sendiri, Bank Indonesia, Ikatan Akuntan Indonesia, Pemerintah dan bagi akademisi.
\end{abstract}

Kata Kunci: SAK-EMKM, SI APIK, UMKM, RPM Institute 


\section{A. PENDAHULUAN}

Permasalahan yang terjadi dan memang dirasakan langsung para pelaku UMKM ScaleUp Jabodetabek adalah kurangnya informasi mengenai cara pencatatan transaksi keuangan usaha yang baik, mudah, namun sesuai dengan standar keuangan yang berlaku. Tidak hanya kurangnya informasi mengenai SAK-EMKM, para pelaku UMKM ScaleUp juga kesulitan dalam mengelola keuangan, pada kenyataannya dilapangan, UMKM masih 'one man show' dalam menjalankan usahanya. Hal ini menyebabkan uang usaha tercampur dengan uang pribadi. Masalah ini hampir terjadi sekitar 90\% UMKM di Tangerang selatan. Perlu adanya metode baru untuk memisahkan pengelolaan uang tersebut. Metode "Dompet Traficlight" dapat menjadi solusi yang ditawarkan kepada para pelaku UMKM dalam mengelola keuangan yang masih dijalankan sendiri.

SI APIK (Sistem Informasi Aplikasi Pencatatan Informasi Keuangan) adalah sistem pencatatan keuangan secara online berbasis Android yang diluncurkan Bank Indonesia. Sistem tersebut akan mempermudah UMKM ScaleUp melakukan pencatatan laporan keuangan secara online. Salah satu keunggulan sistem ini adalah model penginputannya 'single enrty' sehingga tidak perlu pemahaman mengenai akuntansi, siapapun bisa melakukannya. SI APIK diharapkan memberi efek positif bagi aktifitas bisnis para pelaku usaha. Sebab mereka bisa membuat melalui ponsel android dengan mudah. Sistem aplikasi dapat digunakan oleh semua pengusaha UMKM dengan mengunduh program tersebut secara gratis melalui ponsel android di Google Playstore

\section{B. METODE PELAKSANAAN KEGIATAN}

Setelah dipahami, bahwa pencatatan akuntansi keuangan usaha para pelaku UMKM masih menjadi momok yang menakutkan, maka pemecahan permasalahan ketidakdisiplinan pembukuan sederhana akibat kurangnya informasi mengenai standar akuntamsi keuangan yang berlaku bagi UMKM, dilakukan dengan beberapa pendekatan yang dilakukan secara bersama sama yaitu: (1) Berbasis Kelompok pelaku UMKM, (2) Komprehensif dan (3) Berbasis teknologi digital. ketiga metode tersebut diimlementasikan dalam 4 (empat) tahapan yaitu (1) sosialisasi, (2) peningkatan kompetensi, (3) pendampingan (4) monitoring dan evaluasi.

Realisasi pemecahan masalah ketidakdisiplinan pembukuan sederhana akibat kurangnya informasi mengenai standar keuangan yang berlaku bagi UMKM. Jumlah peserta 100 UKM dibagi menjadi 2 kelas dengan 2 sesi, pertama pelaku UMKM berpartisipasi sebagai peserta pelatihan dan kedua pelaku UMKM berpartisipasi sebagai wirausaha yang dilakukan pada sesi pagi dan siang. Kegiatan penyuluhan, pendampingan dan konsultasi dilakukan di kampus Universitas Pamulang, Jl. Surya Kencana No. 1, Pamulang, Kota Tangerang Selatan. Waktu penyuluhan dilakukan di tanggal 24-28 Februari 2020 hari seninjum'at dan selasa sesi I pukul 08:00 - 12:00WIB dan sesi II pukul 13:00 - 17:00WIB. 
Pendampingan dan konsultasi dilakukan pada hari senin - jumat pukul 15:00 dan 20:00 23:00 atau di jam yang telah disepakati. Pelaksanaan kegiatan Pengabdian Pada Masyarakat ini dilakukan dengan menggunakan metode ceramah, tutorial, diskusi, pendampingan dan konsultasi, dan assesment. Adapun sistematika pelaksanaan kegiatan pengabdian ini adalah sebagai berikut:

1. Langkah 1 (Metode Ceramah): Peserta diberikan motivasi agar memiliki kemauan untuk menggunakan akuntansi dalam kegiatan bisnisnya. Selain itu, peserta diberikan materi gambaran umum tentang akuntansi UMKM dan peran penting akuntansi bagi UMKM

2. Langkah 2 (Metode Tutorial): Peserta pelatihan diberikan materi akuntansi mulai dari pencatatan sampai dengan menyusun laporan keuangan dengan SI APIK. Langkah kedua diselenggarakan selama 2 hari, masing-masing 1 jam per hari terbagi dalam dalam 2 sesi, sesi pertama pukul 08:00 - 12:00 dan sesi kedua pukul 13:00 - 17:00.

3. Langkah 3 (Metode Diskusi): Peserta pelatihan diberikan kesempatan untuk mendiskusikan permasalahan yang berkaitan dengan keuangan UMKM yang selama ini dihadapi. Langkah ketiga diselenggarakan selama 1 jam.

4. Langkah 4 (pendampingan dan konsultasi): peserta diberi kesempatan untuk didampingi selama 3 bulan dalam menyusun laporan keuangan. Peserta diberi kesempatan untuk bertemu dengan para mentor di waktu dan tempat yang telah disepakati.

5. Langkah 5 (Evaluasi/ Assesment) : tahap pertama evaluasi, peserta diuji dengan diberi batas waktu apakah mengumpulkan laporan keuangan perusahaannya yang telah diajarkan. Evaluasi tahap kedua, peserta diuji apakah laporan yang disajikan benar atau salah

\section{HASIL DAN PEMBAHASAN}

Kegiatan pelatihan akuntansi UMKM bagi UMKM untuk meningkatkan bonafiditas dan kedisplinan pelaku UKM, dilaksanakan selama 5 tahap dalam beberapa hari. Adapun susunan acara pelatihan sebagai berikut:

\section{Tabel 1.1 Susunan Acara Pelatihan}

\begin{tabular}{|c|l|l|c|}
\hline No & Hari, Tanggal & Materi & Waktu \\
\hline \multirow{2}{*}{1} & \multirow{2}{*}{ Senin, 24 Februari } & $\begin{array}{l}\text { Q and A general finance } \\
\text { Peserta }\end{array}$ & $\begin{array}{l}\text { Pengantar /Pendahuluan } \\
\text { Akuntansi (SAK-EMKM) }\end{array}$ \\
\cline { 3 - 4 } & $\begin{array}{l}\text { Transaksi Akuntansi sekaligus } \\
\text { latihan SI APIK }\end{array}$ & $09: 09: 00-09: 30$ \\
\hline 2 & $\begin{array}{l}\text { Selasa s.d Jum'at 25- } \\
\text { 28 Februari 2020 }\end{array}$ & $\begin{array}{l}\text { Pendampingan/Konsultasi } \\
\text { UKM }\end{array}$ & Waktu disesuaikan \\
\hline
\end{tabular}


Pelaksanaan pelatihan Pada hari Senin 24 Februari 2020 dari pukul 08.00 sampai dengan 12.30. Acara pertama diawali dengan registrasi peserta sekaligus mengisi Tanya jawab seputar keuangan umum usaha peserta. Selanjutnya, dilanjutkan dengan sambutan oleh Ibu Effryanti, SE., Ak., MSi., CA selaku Ketua Program Studi Akuntansi S1 Universitas Pamulang, sambutan Ketua RPM dan pembagian kelompok UKM oleh Ibu Ratih Qadarti Anjilni, SE., M.Ak. yang akan dibina oleh anggota pengabdi. Selanjutnya langsung dilakukan pendampingan dengan kelompok masing-masing s.d selesai pukul 12:30 (sesi pagi).

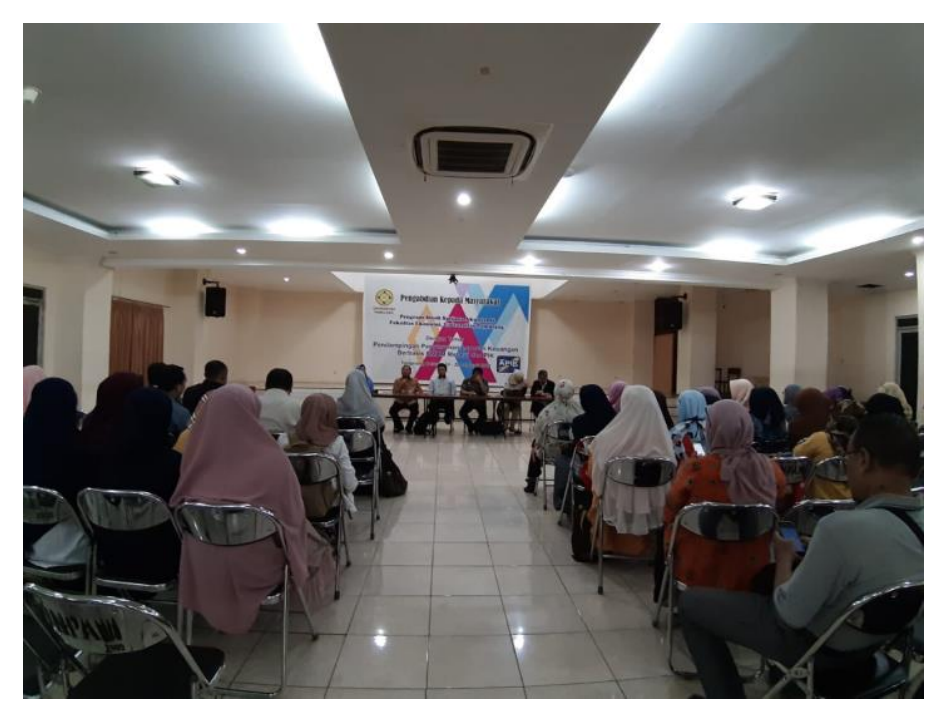

\section{Gambar 1}

\section{Sambutan, Penyampaian Materi dan Tanya Jawab}

Pelaksanaan pelatihan pembuatan laporan keuangan UMKM yang berdasarkan pada Standart Akuntansi Keuangan EMKM atau biasa disingkat dengan SAK EMKM dengan Menggunakan aplikasi SIAPIK, dilaksanakan pada hari senin 24 Februari 2020 dimulai pada pukul 10.00 di aula rektorat gedung Universitas Pamulang. Pelaksanaan pelatihan dibagi menajdi 2 sesi pelatihan mengingat banyaknya jumlah UMKM yang berpartisipasi pada pelatihan ini. 


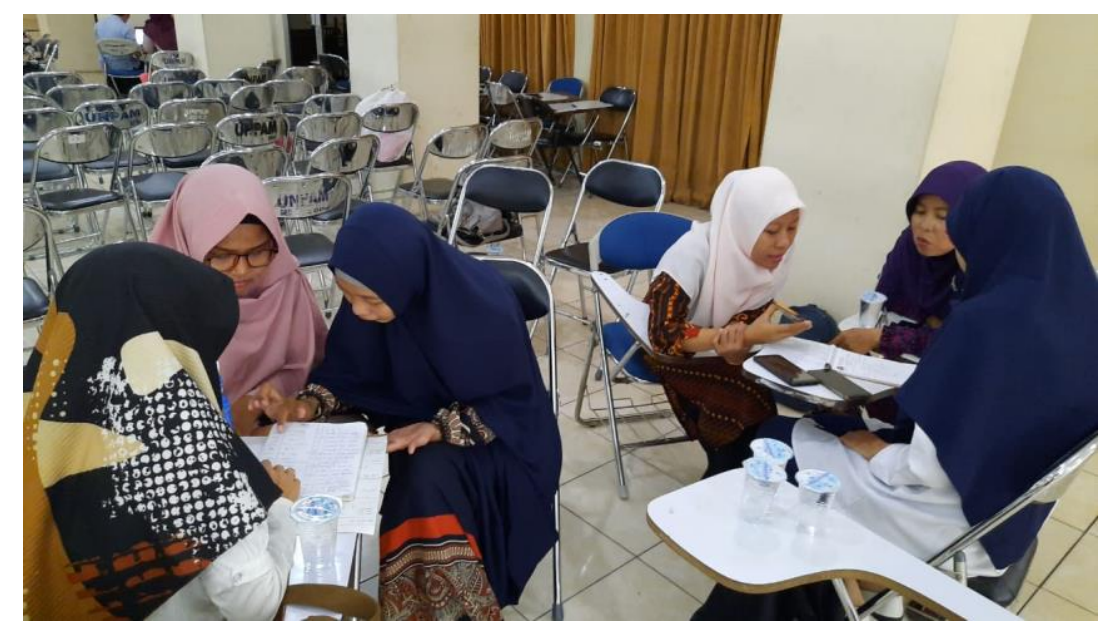

Gambar 2

\section{Pendampingan Penggunaan SI APIK}

Pada kelompok kami mendapatkan sesi yang pertama dengan bidang wirausaha manufaktur. UMKM yang kita bantu dalam penyusunan laporan keuangannya terdiri dari "Peyek Mak Esti" yaitu Bu Esti sendiri yang bertindak sebagai Owner dan usaha peyek rumahan ini sudah berjalan sejak tahun 2017 dengan modal pertama sebesar Rp. 500.000 dengan pangsa pasar adalah pelanggan warung yang berada pada lingkungan rumah Bu Esti sendiri. Dan UMKM yang kedua merupakan usaha bandeng presto, meskipun usaha yang dilakukan oleh $\mathrm{Bu}$ Felly ini cukup beragam, mulai dari jahe jeruk lemon atau disingkat dengan "Jerman" sampai dengan tahu krispi yang dikemas semenarik mungkin guna menarik pembeli. Namun produk bandeng presto merupakan produk unggulan dari usaha yang sudah didirikan kurang lebih 5 tahun ini.

Setelah pengenalan masing-masing usaha, kami mulai mempelajari catatan-catatan transaksi yang telah dibuat oleh masing-masing owner dari UMKM tersebut. Laporan yang mereka buat sudah cukup baik meskipun masih ada yang harus diperbaiki. Kemudian, kami mulai membantu owner-owner tersebut untuk memasukkan data-data transaksi yang telah mereka buat kedalam aplikasi SIAPIK, agar dari data transaksi yang sederhana itu dapat tercipta laporan keuangan yang baik yang sesuai dengan standart akuntansi keuangan EMKM.

Pada pelatihan pembuatan laporan keuangan UMKM ini dengan menggunakan aplikasi SIAPIK, diharapkan dari penginputan data transaksi tersebut terbentuklah laporan keuangan yang baik sehingga dapat menarik pihak investor untuk menanamkan modalnya pada UMKM ini.

\section{KESIMPULAN DAN SARAN}

\section{Simpulan}

Kegiatan pelatihan akuntansi UMKM bagi usaha mikro, kecil, menengah (UMKM) untuk meningktakan bonafiditas perusahaan berjalan dengan lancar. Sekaligus meningkatkan 
kedisplinan pelaku UMKM terhadap pencatatan akuntansi. Semua peserta antusias mengikuti acara hingga selesai dan merasakan manfaat pelatihan bagi kemajuan usaha mereka

\section{Saran}

Serupa dapat dilaksanakan kembali dengan peserta (audience) yang lebih banyak/luas, dan dengan topik lainnya. Di samping itu fasilitas untuk presentasi seperti ruangan AC, pengeras suara sebaiknya diperiksa kembali sebelum acara dilaksanakan

\section{Ucapan Terima Kasih}

Acara dapat terselenggara dengan baik, penulis pada kesempatan kali ini inginmengucapkan terimakasih kepada Rumah Pemberdayaan Masyarakat (RPM) Institute Tangerang Selatan yang telah berpartisipasi dalam kegiatan ini. Terima kasih juga disampaikan untuk Universitas Pamulang yang telah bersedia memfalisitasi kegiatan tersebut.

\section{DAFTAR PUSTAKA}

Exposure Draft Standar Akuntansi Keuangan Entitas Mikro Kecil Menengah (SAK-EMKM). 2016. IAI: Jakarta Selatan.

Pedoman Teknis Pencatatan Transaksi Keuangan Usaha Kecil Badan Usaha Bukan Badan Hukum Sektor Perdagangan. 2015. Bank Indonesia: Jakarta

RPIJM (Rencana Program Investasi Jangka Menengah) Bidang Cipta Karya Tahun 20192023. 2019. Tangerang Selatan. Bab 2.

Setyorini, dkk. (2012). Pelatihan Akuntansi UMKM Bagi UMKM Untuk Meningkatkan Kinerja Keuangan Perusahaan. UNY.

Solihin, D. (2019), Pengaruh Current Ratio Dan Debt To Equity Ratio Terhadap Return On Asset (ROA) Pada PT Kalbe Farma, Tbk, KREATIF: Jurnal Ilmiah Prodi Manajemen Universitas Pamulang 7 (1).

Standar Akuntansi Keuangan Entitas Mikro Kecil Menengah (SAK-EMKM). 2018. IAI: Menteng. Jakarta Selatan. 